\title{
Pengembangan Sistem Pengelolaan Informasi Pusat Informasi dan Konseling Remaja Kota Padang
}

\author{
Isra Wilna1, Haris Suryamen¹, Fajril Akbar1 \\ 1 Jurusan Sistem Informasi, Fakultas Teknologi Informasi, Universitas Andalas, Padang, INDONESIA
}

(corresponding author) ijab@fti.unand.ac.id *)

\begin{abstract}
A functions of Pusat Informasi dan Konseling (PIK) remaja is giving information service and counseling on planning their future life. Most of them are located in educational institutions such as schools and universities and others also being a part of noneducational background. They located spreadly in 11 districts of Padang. Each PIK remaja, are required to submit their programme report periodically to local government that called as BPMPKB Padang. Within limitations of space and time, BPMPKB had difficulity in handling its function as controller. In addition, address of PIK remaja it is unknown because it never reported. Therefore a system can resolve this issue is Geographic information system. It able to present information based on a geographic reference. By support with web, a geographic visualization will facilitate the stakeholders in monitoring of PIK remaja at Padang. A software development method is adopted waterfall model. System involved 3 type of actors consist of common user, BPMPKB user and PIK remaja user. As common user, its feature is capable in searching PIK remaja based on category, region, nearest PIK remaja with user's location, route to selected PIK remaja. On the other hand, BPMPKB user also can manage data and regular report from PIK R. In addition, PIK remaja user can manage data and submit their report. Database consists of 9 tables with 17 design application user interfaces. Application testing is done by functional validation using Blackbox test. It involved 5 testers and it recommended that functional of application is fulfilled with user needed.
\end{abstract}

Keywords: PIK Remaja, Geographic Information System.

Intisari - Salah satu fungsi dari Pusat Informasi dan Konseling (PIK) remaja adalah memberikan pelayanan informasi dan konseling tentang perencanaan kehidupan berkeluarga bagi remaja. PIK remaja ini banyak terdapat di lembaga pendidikan sepert sekolah dan perguruan tinggi maupun lembaga non pendidikan. Lokasinya tersebar di 11 kecamatan yang ada di Kota Padang. Setiap PIK remaja, diharuskan menyampaikan laporan-nya secara kolektif dan berkala ke Badan Pemberdayaan Masyarakat, Perempuan dan Keluarga Berencana (BPMPKB) Padang,. Keterbatasan ruang dan waktu, menjadi kendala bagi BPMPKB dalam menjalan perannya sebagai pengawas. Disamping itu, perubahan alamat kantor PIK remaja banyak tidak terkelola karena tidak terdokumentasi dengan baik. Oleh karena itu dibangun sebuah sistem yang mampu menyelesaikan masalah tersebut. Sistem infomasi geografis menjadi pilihan karena mampu menyajikan informasi dengan referensi geografis. Dukungan teknologi web terhadap visualisasi geografis akan memudahkan pemangku kebijakan dalam pengembangan PIK remaja di Kota Padang. Metode pengembangan aplikasi mengadopsi model waterfall. Sistem yang dibangun memiliku 3 aktor penggunan yangn terdiri dari pengguna biasa, BPMPKB dan PIK remaja. Aplikasi telah dibangun dengan fungsional pengguna biasa adalah melakukan pencarian PIK remaja berdasarkan kategori, berdasarkan wilayah, pencarian PIK remaja yang terdekat dari posisi pengguna, melihat rute menuju PIK remaja yang dipilih. Disamping itu pengguna BPMPKB dapat mengelola data dan laporan kegiatan PIK remaja. Pengguna PIK remaja dapat mengelola data PIK-nya serta menyampaikan laporan kegiatan secara online. Semua data tesimpan dalam database terdiri dari 9 tabel dengan 17 rancangan user interface aplikasi. Pengujian dilakukan dengan validasi fungsional aplikasi yang dirancang dengan aplikasi secara Blackbox testing. Pengujian ini melibatkan 5 orang pengguna dengan hasil rekomendasi fungsional dari sistem telah berjalan sesuai dengan rancangan.

Kata kunci: PIK remaja, Sistem Informasi Geografis.

\section{PENDAHULUAN}

\section{A. Latar Belakang}

PIK remaja merupakan suatu wadah kegiatan program Penyiapan Kehidupan Berkeluarga bagi Remaja (PKBR) guna memberikan pelayanan informasi dan konseling tentang perencanaan kehidupan berkeluarga bagi remaja yang berada dibawah pengendalian Badan Pemberdayaan Masyarakat, Perempuan dan Keluarga Berencana (BPMPKB). Disamping memberikan informasi terkait PKBR, PIK remaja juga memberikan informasi tentang pendewasaan usia perkawinan, 
keterampilan hidup dan layanan konseling. Keberadaan PIK remaja menjadi penting dalam kaitannya dengan pemberian pelayanan informasi dan konseling bagi kalangan remaja [1] [2][3][4]. Saat ini 58 PIK remaja yang berasal dari jalur sekolah, jalur luar sekolah, dan jalur perguruan tinggi yang tersebar di 11 kecamatan di Kota Padang [5],

Bagi pihak BPMPKB, dalam pengelolaan dan pengawasan PIK remaja mengalami kendala dalam proses pengumpulan laporan dari masing-masing PIK remaja, karena laporan tersebut dikumpulkan dengan mendatangi lokasi setiap PIK remaja yang ada. Banyak dari PIK yang merubah alamat tanpa terpantau oleh pihak BPMPKB[6]. Di kalangan remaja juga banyak yang tidak mengetahui keberadan PIK remaja di lingkungan mereka, terutama PIK remaja yang berada pada jalur luar sekolah. Oleh karena itu diperlukan suatu sistem yang mampu mengintegrasikan, mengolah, dan menyajikan informasi spasial (ruang) dan atribut dari PIK remaja yang ada di Kota Padang. Penggunaan web akan mempermudah akses terhadap informasi, karena teknologi ini memberikan layanan akses melalui internet yang saat ini tersedia dimana-mana[7].

Pemanfaatan sistem informasi geografis (SIG) sebagai portal informasi telah diimplementasikan sebagai sistem bagi informasi lapangan futsal dan lembaga bimbingan belajar di kota Padang [8][9]. SIG juga mampu merekomendasikan rute terdekat pada peta dengan berbagai metode [10]. Oleh karena itu, keharusan setiap PIK remaja untuk menyampaikan laporan kepada pemerintah [11], dapat diterapkan pada sebuah sistem yang berbasis web. Dalam penelitian ini dikembangkan sebuah sistem informasi geografis bagi PIK remaja Kota Padang yang berbasis Web.

\section{METODOLOGI PENELITIAN}

Pada tahap awal dirumuskan kebutuhan fungsional dari sistem. Kebutuhan ini didapatkan dari dokumen yang ada dan wawancara dengan pengguna aplikasi diantaranya pihak BPMPKB. Pengumpulan data spasial dilakukan dengan digitalisasi setiap lokasi PIK remaja dan data atribut didapat dari pihak BPMPKB. Pada tahapan perancangan dilakukan perancangan arsitektur aplikasi, basis data dan antar muka aplikasi. Pemodelan dengan UML juga dilakukan dengan usecase dan context diagram. Tahapan pembangunan dilakukan berdasarkan rancangan yang ada serta serta tahapan akhir dari penelitian ini adalah pengujian kebutuhan fungsional aplikasi oleh pengguna secara blackbox testing. Metode penelitian dapat dilihat pada gambar 1.

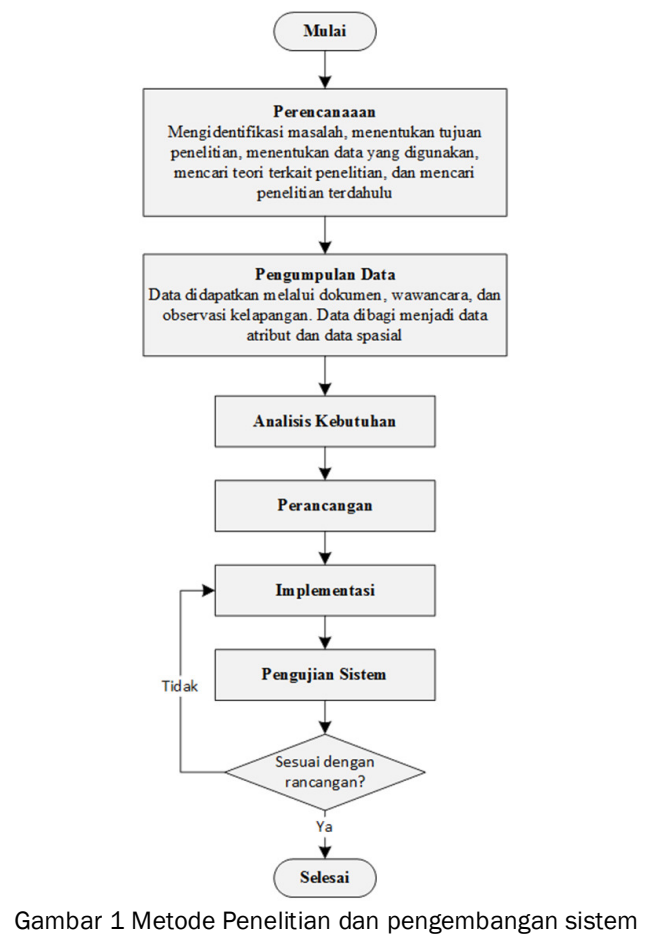

Data atribut dan data spasial digunakan dalam aplikasi ini. Data atribut yang digunakan yaitu data PIK remaja tahun 2016 yang didapat dari BPMPKB Kota Padang. Data tersebut terdiri dari nama, alamat, kategori dan pengurus PIK 
Remaja. Data spasial diperoleh dari hasil digitasi obyek pada peta Google Maps 2016 dari Kota Padang. Data spasial ditampilkan pada peta dasar Google Maps. Aplikasi ini hanya bisa menyajikan data atribut yang telah tersimpan di basis data serta data spasial adalah hasil digitasi dari objek yang telah di observasi disetiap lokasi. Disamping itu, untuk kebutuhan aplikasi digunakan peta dasar Google Maps dengan pemakaian fungsi Google Maps API.

\section{PERANCANGAN DAN IMPLEMENTASI}

A. Analisis Kebutuhan

1) Kebutuhan Fungsional: Fungsional sistem merupakan kegiatan yang dapat dilakukan oleh sistem yang didapatkan dari wawancara dan penelitian aplikasi sejenis. Fungsional sistem yang dibangun untuk aplikasi ini adalah sebagai berikut:

1. Pengguna dapat melakukan pencarian PIK remaja berdasarkan kategori,nama dan wilayah

2. Pengguna dapat melakukan pencarian PIK remaja yang terdekat dari posisi pengguna.

3. Pengguna dapat melihat informasi PIK remaja seperti nomor SK, nama, alamat, pembina, jalur, dan kategori.

4. Pengguna dapat melihat rute menuju PIK remaja yang dipilih dari posisi user saat ini.

5. Pengguna yang tervalidasi sebagai pihak BPMPKB dapat mengelola data PIK remaja.

6. Pengguna yang tervalidasi sebagai pihak BPMPKB mengunduh laporan dari setiap PIK remaja

7. Pengguna yang tervalidasi sebagai pihak PIK remaja dapat mengunggah laporan

8. Pengguna yang tervalidasi sebagai pihak PIK remaja dapat mengubah informasi PIK-nya

Untuk kebutuhan non-fungsional dari sistem adalah:

1. Sistem memerlukan koneksi internet untuk dapat mengakses peta Google Maps.

2. Sistem dapat diakses dengan menggunakan layanan internet.

3. Sistem memerlukan perangkat pendeteksi posisi pengguna.

2) Context Diagram: Context diagram dari aplikasi merupakan diagram yang menggambarkan interaksi sistem dengan penggunanya. Context diagram dari aplikasi dapat dilihat pada gambar 2. Pada context diagram ini dapat dilihat bahwa sistem memiliki empat entitas yaitu pengguna, pengguna BPMPKB, pengguna PIK remaja, dan Google Maps.

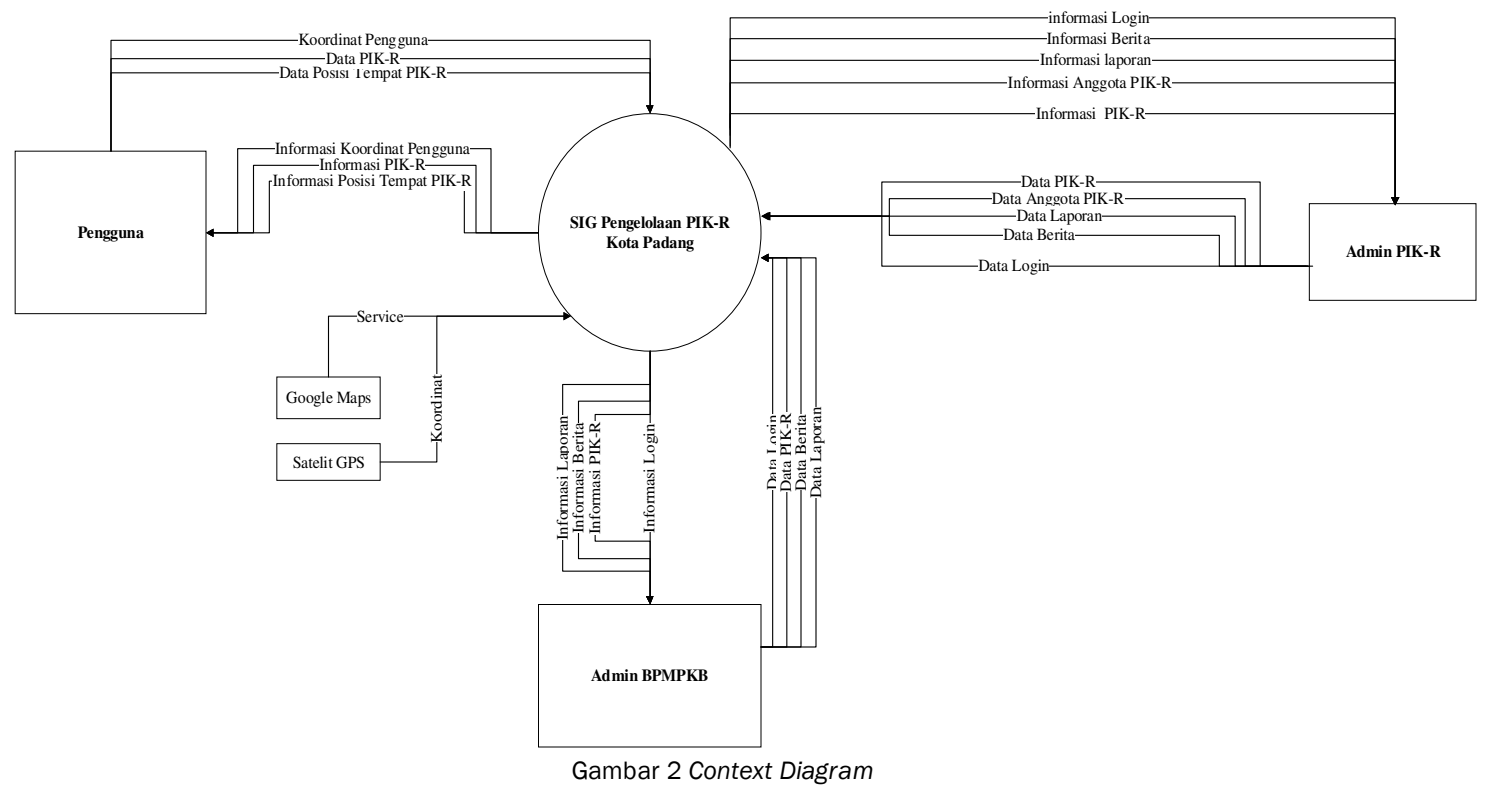


3) Data Flow Diagram: Kebutuhan dalam use case diagram adalah kebutuhan fungsional aplikasi. Berdasarkan analisis kebutuhan terhadap sistem yang akan dibuat maka use case diagram yang dihasilkan dapat dilihat pada gambar 3 .

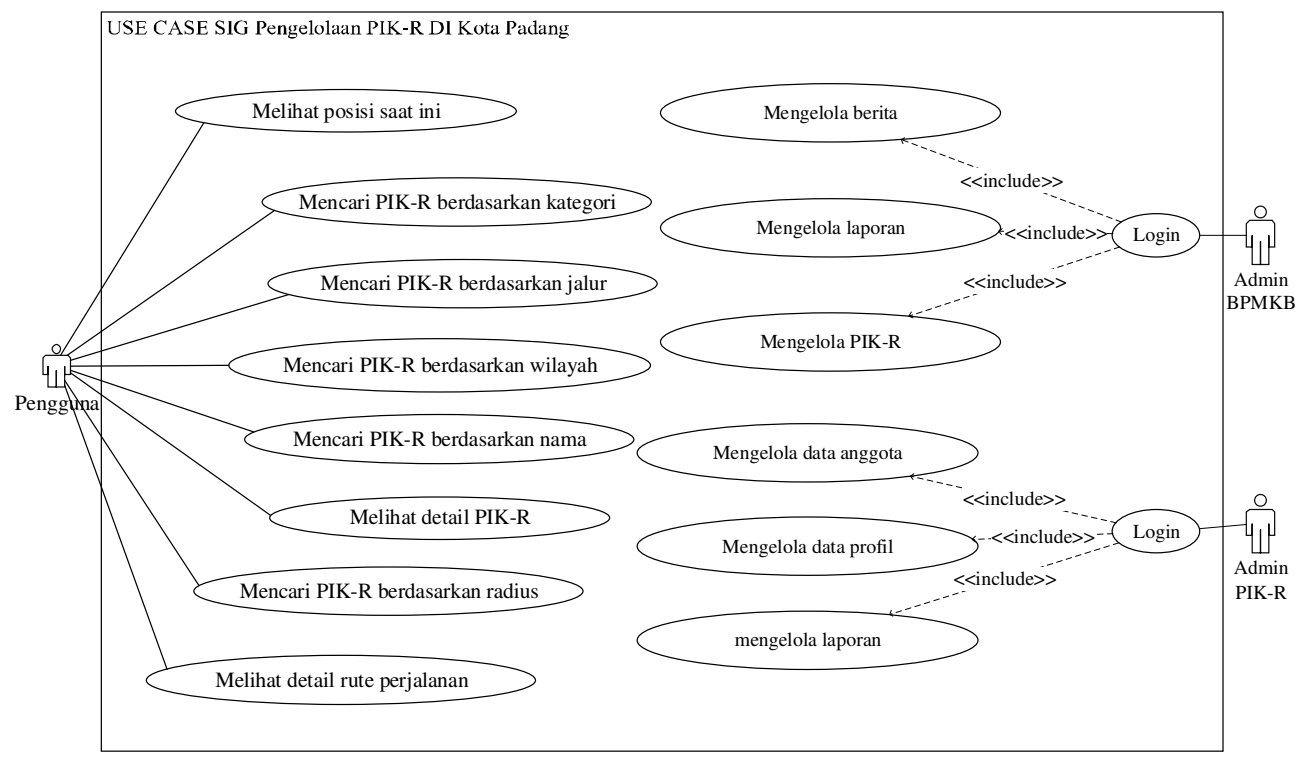

Gambar 3 Use-case diagram

B. Rancangan Sistem

1) Arsitektur sistem: aplikasi SIG ini membutuhkan teknologi pendukung antara lain Maplnfo Professional, PostgreSQL, PostGIS, web browser, web server dan Google Maps. Gambar 4 merupakan ilustrasi arsitektur sistem yang dibangun.

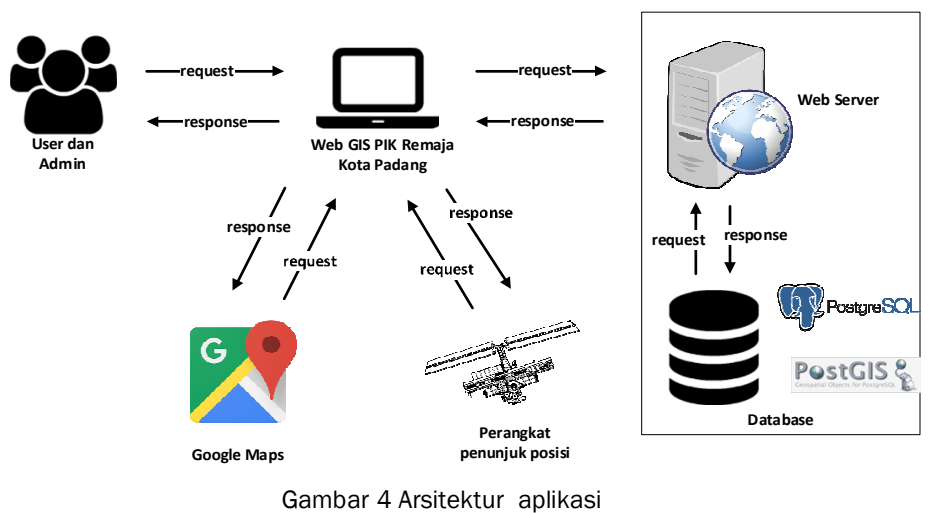

2) Rancangan Basis Data: Berdasarkan analisis kebutuhan sistem sebelumnya, basis data yang dirancang untuk pemetaan PIK remaja di Kota Padang berbasis web terdiri dari sembilan tabel. Data geometry pada aplikasi di tampung pada tabel kecamatan, kelurahan, dan pik_r. Tabel relasi pada basis data pemetaan PIK remaja di Kota Padang berbasis web dapat dilihat pada Gambar 5. 

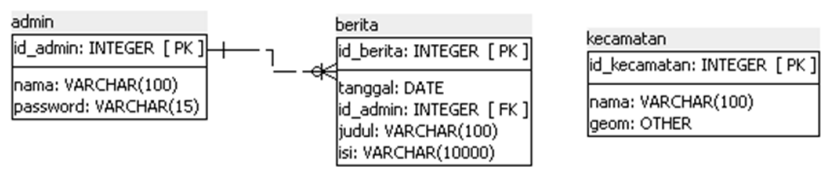

kelurahan

id_kelurahan: INTEGER [ PK ]

nama: VARCHAR(100)

geom: OTHER

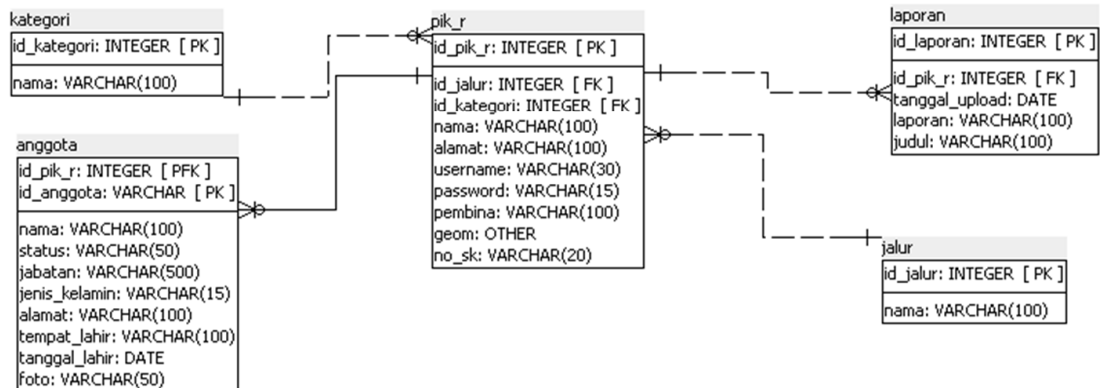

Gambar 5 Tabel relasi sistem

3) Rancangan User Interface: Rancangan user interface disusun dengan menyesuikan dengan fungsional aplikasi yang ada. Gambar 6 merupakan rancangan tampilan dan pencarian.

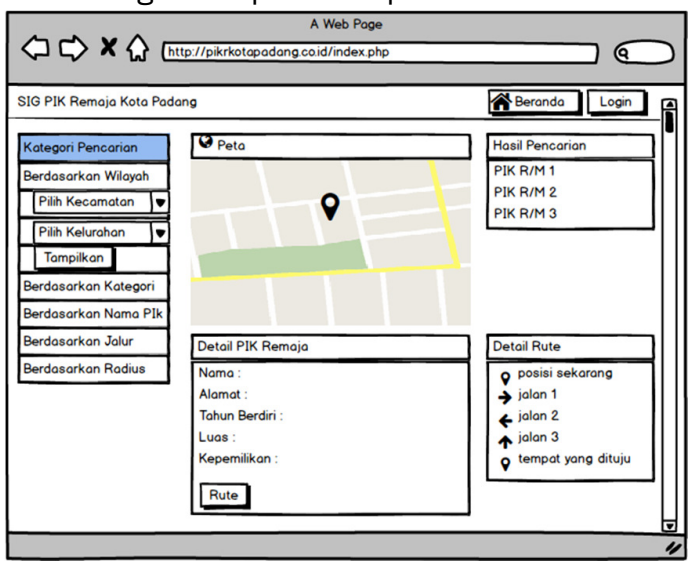

Gambar 6 Rancangan halaman peta

\section{Implementasi Rancangan}

Tahap implementasi dilakukan setelah melakukan analisis dan perancangan sistem. Implementasi dari SIG terdiri dari tiga bagian, yaitu implementasi basis data, implementasi user interface dan implementasi program. Salah satu implementasi user interface untuk melihat rute dapat dilihat pada gambar 7 . 


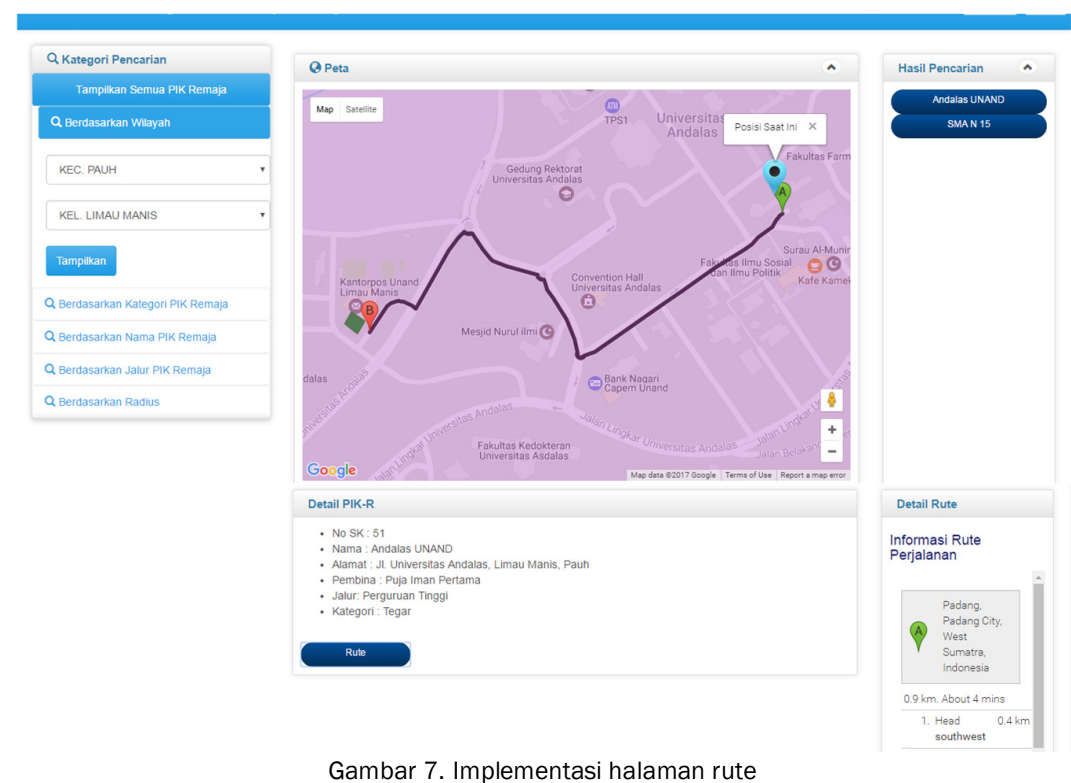

Untuk implementasi perangkat keras, aplikasi telah di instalasi pada server dengan IP Address 205.251.137.35 dan nama domain http://gisfaisal.in/pikr. Perangkat lunak untuk basis data menggunakan PostgreSQL v9.3.0 dengan ekstensi PostGIS v2.1.0. Kode aplikasi dimplementasi dalam bahasa PHP dan JavaScript. Salah satu contoh algoritma aplikasi untuk pencari berdasarkan nama PIK remaja dapat dilihat pada gambar 8.

1 Input nama PIK

2 Ambil informasi PIK Remaja untuk nama=nama PIK.

3 Ambil semua id_pik_r untuk NAMA = nama pada tabel penghubung dan simpan pada tabel A.

4 Untuk setiap record pada tabel $A$.

5 Ambil informasi PIK remaja (spasial dan atribut) pada tabel pik_ $r$ berdasarkan id_pik_ $r=$ A.id_pik_r.

6 Loop.

7 Tampilkan informasi yang ada.

8 Selesai.

Gambar 8. Algoritma Pencarian berdasarkan nama

\section{A. Pengujian Sistem}

\section{PENGUJIAN DAN HASIL}

Pengujian dengan black-box testing difokuskan pada rancangan kebutuhan fungsional dari perangkat lunak. Jika output dari sistem sesuai dengan kebutuhan fungsionalnya, maka sistem dinyatakan telah memenuhi kebutuhan yang ditetapan. Beberapa pengujian yang dilakukan yaitu, pengujian melihat informasi PIK remaja oleh pengguna, pengujian mencari PIK dalam radius terdekat dengan pengguna, dan pengujian pengelolaan data PIK remaja oleh admin BPMPKB. Pengujian aplikasi dilakukan oleh lima orang pengguna yaitu kepala bidang KB/KS BPMPKB Kota Padang, koordinator pengelolaan program PIK Remaja BPMPKB, anggota PIK Remaja di Kota Padang, pelajar, dan mahasiswa. 
1) Pengujian Melihat Detail PIK remaja: Pengujian ini sistem akan menampilkan informasi detail salah satu PIK Remaja. Prosedur pengujian melihat informasi detail PIK remaja dapat dilihat pada Tabel 1. Hasil tampilan dari pengujian melihat informasi detail PIK Remaja pada aplikasi Web dapat dilihat pada gambar 9. Untuk pengujian secara manual menggunakan basis data dapat dilihat pada gambar 10.

Tabel 1

Pengujian Melihat Detail Pik Remaja

\begin{tabular}{|l|l|}
\hline Aksi & Pengguna memilin PIK Remaja Andalas UNAND pada hasil pencarian \\
\hline Ekspektasi & $\begin{array}{l}\text { Tampil informasi detail PIK Remaja Andalas UNAND pada kolom detail PIK } \\
\text { Remaja }\end{array}$ \\
\hline Hasil & $\begin{array}{l}\text { Tampil informasi detail No.SK, nama, alamat, pembina, jalur, kategori serta } \\
\text { tombol rute menuju PIK Remaja Andalas UNAND pada kolom detail PIK Remaja }\end{array}$ \\
\hline Kesalahan & Tidak ada \\
\hline Hasil Pengujian & Sesuai dengan ekspektasi \\
\hline
\end{tabular}

Detail PIK-R

- No SK : 51

- Nama : Andalas UNAND

- Alamat : Jl. Universitas Andalas, Limau Manis, Pauh

- Pembina : Puja Iman Pertama

- Jalur: Perguruan Tinggi

- Kategori : Tegar

Rute

Gambar 9. Hasil Pengujian Melihat Detail PIK Remaja pada Aplikasi Web

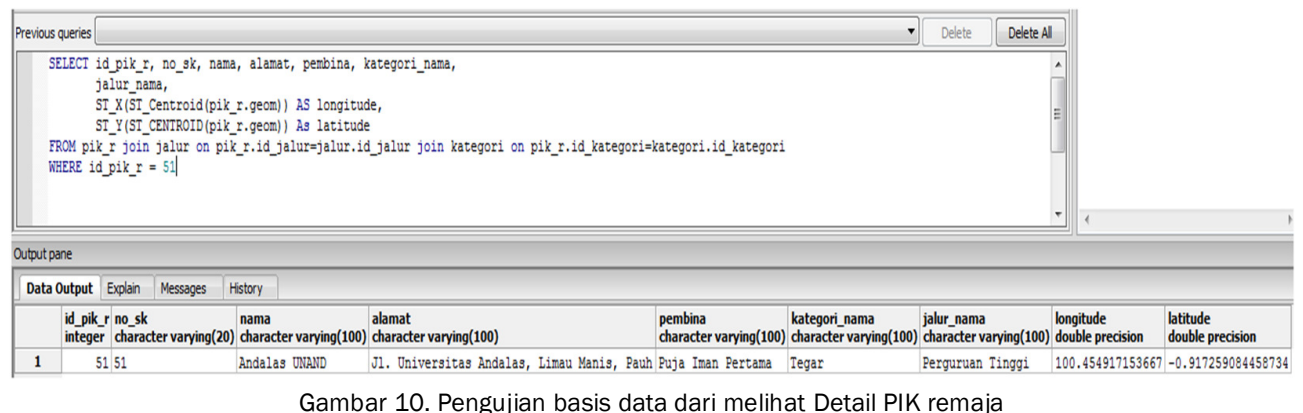

Gambar 10. Pengujian basis data dari melihat Detail PIK remaja

2). Pengujian Mencari PIK Remaja Berdasarkan Radius Terdekat dari Posisi Pengguna: Hasil akhir yang diharapkan dari pengujian mencari PIK remaja berdasarkan radius terdekat dari posisi pengguna adalah muncul marker pada peta dan nama PIK remaja pada hasil pencarian sesuai dengan radius yang diinputkan. Kriteria pengujian mencari PIK remaja berdasarkan radius terdekat dari posisi pengguna dapat dilihat pada Tabel 21. Hasil tampilan dari pengujian mencari PIK remaja berdasarkan radius terdekat dari posisi pengguna pada aplikasi web dapat dilihat pada Gambar .

Tabel 21.

Pengujian Mencari PIK Remaja Berdasarkan Radius Terdekat Dari Posisi Pengguna

\begin{tabular}{|l|l|}
\hline Aksi & $\begin{array}{l}\text { Pengguna memilih menu pencarian “Berdasarkan Radius", lalu menentukan radius } \\
3000 \text { meter }\end{array}$ \\
\hline Ekspektasi & $\begin{array}{l}\text { Muncul marker pada peta dan nama PIK Remaja pada hasil pencarian yang berada } \\
3000 \text { meter disekitar posisi saat ini pengguna }\end{array}$ \\
\hline Hasil & $\begin{array}{l}\text { Muncul PIK Remaja Andalas UNAND, SMA N 15, SMAKPA, dan SMP N } 23 \text { serta } \\
\text { marker pada peta. }\end{array}$ \\
\hline Kesalahan & Tidak ada \\
\hline Hasil Pengujian & Sesuai dengan ekspektasi \\
\hline
\end{tabular}




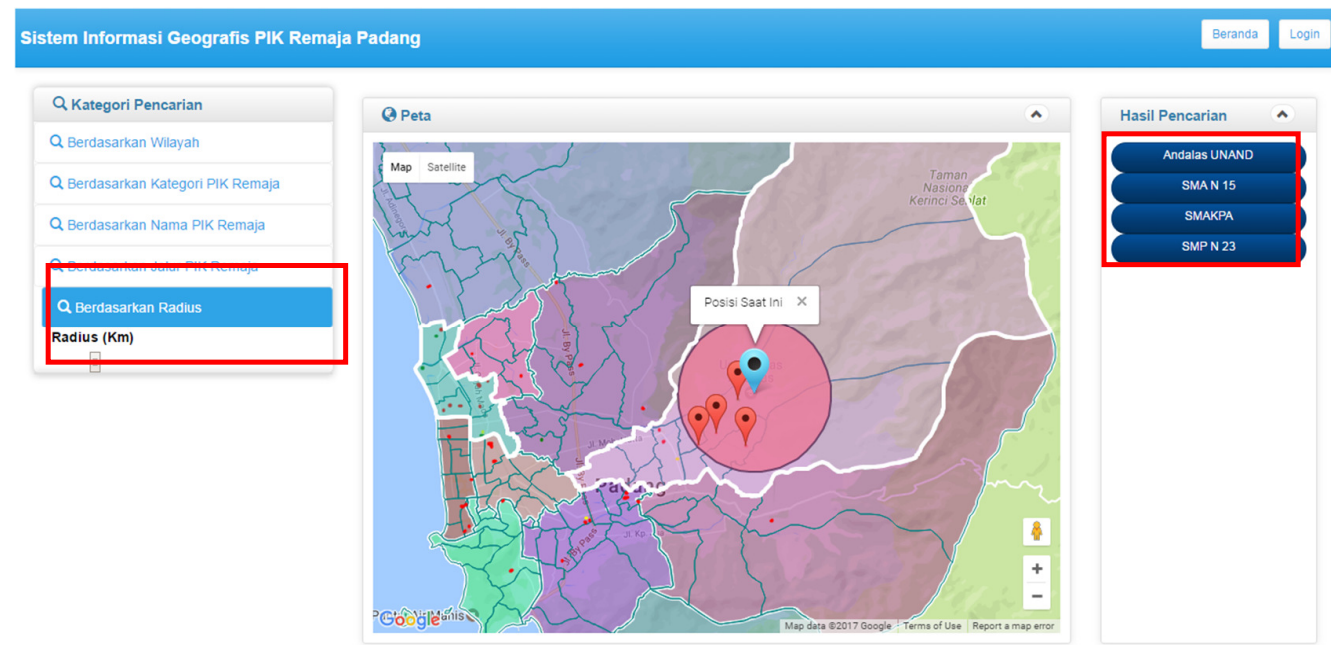

Gambar 11. Hasil Pengujian Mencari PIK Remaja Berdasarkan Radius Terdekat Dari Posisi Pengguna

3). Pengujian Mengelola PIK Remaja: Pengujian mengelola PIK remaja terdiri dari melihat data PIK remaja, menambah dan mengubah data PIK Remaja. Mengelola data PIK remaja ini hanya dapat dilakukan oleh pengguna BPMPKB yang telah login pada aplikasi.

\section{a. Melihat Data PIK Remaja}

Hasil akhir yang diharapkan dari pengujian melihat data PIK remaja adalah admin BMPPKB dapat melihat data PIK remaja pada aplikasi. Kriteria pengujian melihat data PIK remaja dapat dilihat pada Tabel 2. Hasil tampilan dari pengujian melihat data PIK remaja pada aplikasi Web dapat dilihat pada Gambar .

Tabel 2.

Pengujian Melihat Data PIK Remaja

\begin{tabular}{|l|l|}
\hline Aksi & Admin BPMPKB memilih menu PIK-R \\
\hline Ekspektasi & $\begin{array}{l}\text { Tampil list dan informasi logo, No.SK, Nama PIK Remaja, alamat, pembina, } \\
\text { kategori, dan jalur PIK Remaja }\end{array}$ \\
\hline Hasil & $\begin{array}{l}\text { Tampil list dan informasi logo, No.SK, Nama PIK Remaja, alamat, pembina, } \\
\text { kategori, dan jalur PIK Remaja }\end{array}$ \\
\hline Kesalahan & Tidak ada \\
\hline Hasil Pengujian & Sesuai dengan ekspektasi \\
\hline
\end{tabular}

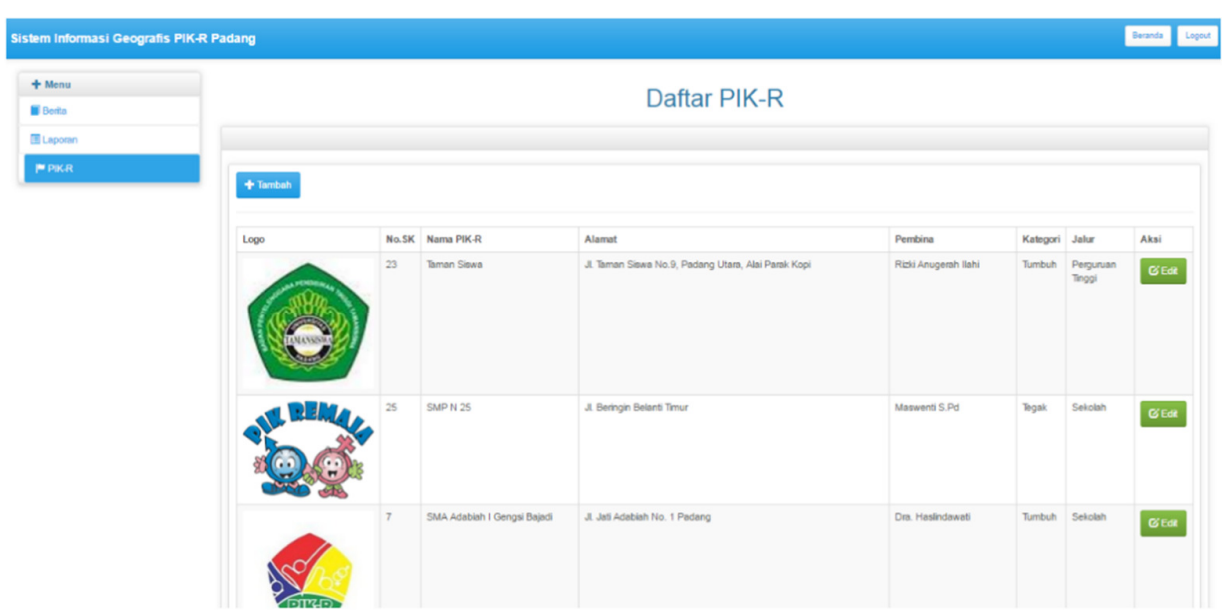

Gambar 12. Hasil Pengujian Melihat Data PIK Remaja pada Aplikasi Web 


\section{b. Menambah Data PIK Remaja}

Hasil akhir yang diharapkan dari pengujian menambah data PIK remaja adalah admin BPMPKB dapat menambahkan data PIK remaja pada aplikasi web. Kriteria pengujian menambahkan data PIK remaja dapat dilihat pada Tabel . Hasil tampilan dari pengujian dapat dilihat pada Gambar. Hasil pengujian dibandingkan dengan keluaran basis data sistem yang dilihat pada Gambar .

Tabel 4.

Pengujian Menambah Data PIK Remaja

\begin{tabular}{|l|l|}
\hline Aksi & $\begin{array}{l}\text { Admin BPMPKB memasukkan data PIK Remaja Taman Siswa dan mendigitasi posisi } \\
\text { PIK Remaja Taman Siswa, lalu menekan tombol “Tambah” }\end{array}$ \\
\hline Ekspektasi & Data PIK Remaja Taman Siswa berhasil ditambah dan masuk ke dalam database \\
\hline Hasil & Data PIK Remaja Taman Siswa berhasil ditambah dan masuk ke dalam database \\
\hline Kesalahan & Tidak ada \\
\hline Hasil Pengujian & Sesuai dengan ekspektasi \\
\hline
\end{tabular}
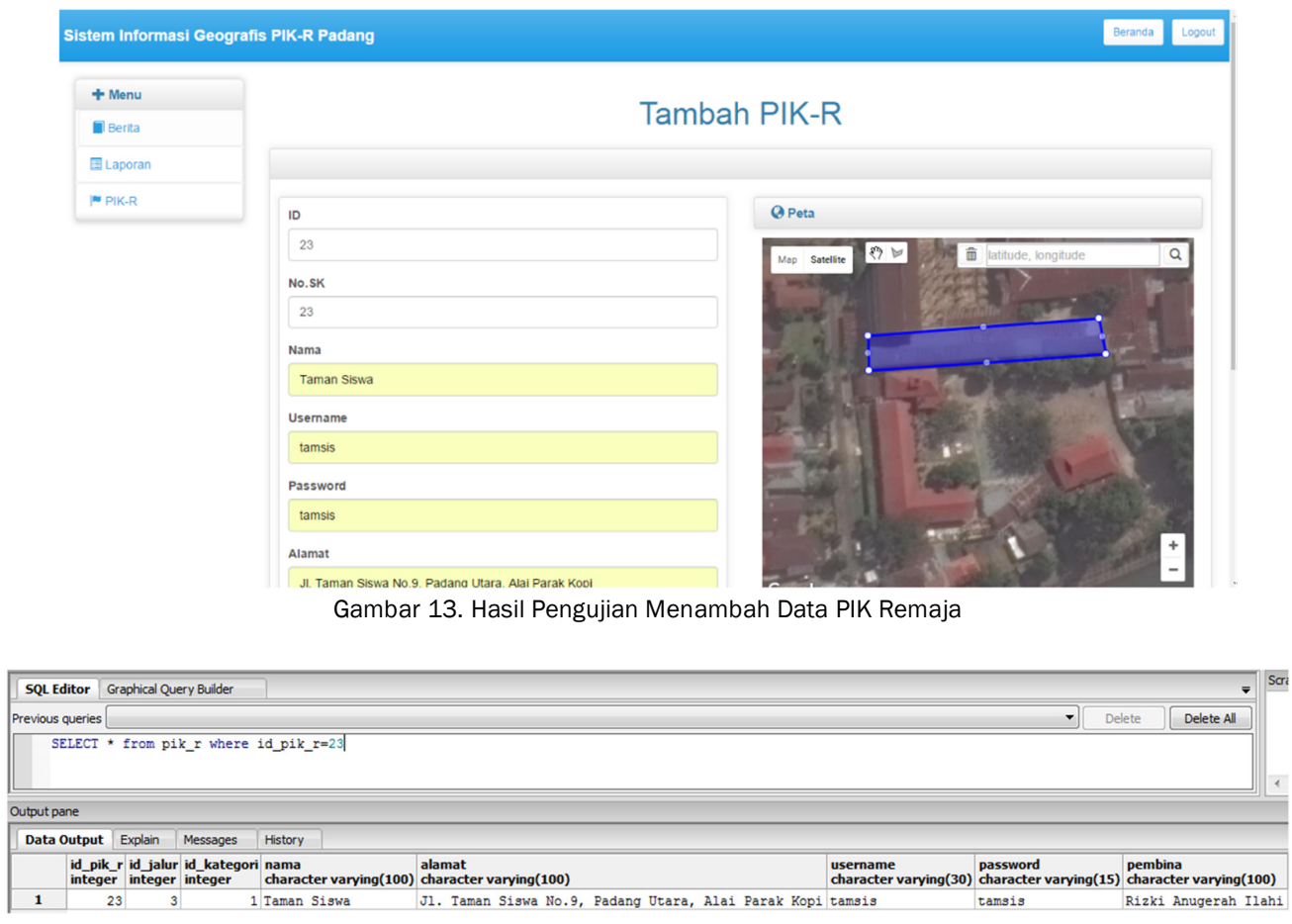

Gambar 14. Data spatial Data PIK Remaja Taman Siswa Telah Berhasil Ditambahkan ke Database

Berdasarkan hasil pengujian yang telah dilakukan oleh 5 pengguna dan perbandingan luaran sistem dengan luaran database, sistem yang dibangun sepenuhnya telah memenuhi kebutuhan fungsional yang dirancang. 


\section{KESIMPULAN}

Dalam proses pembangunan sistem yang dimulai dari tahap analisis kebutuhan, perancangan, implementasi, dan pengujian, maka dapat dirumuskan bahwa SIG PIK Remaja di Kota Padang berbasis web telah berhasil dibangun dan bisa diakses melalui http://gisfaisal.in/pikr. Sistem dibangun dengan melibatkan 3 aktor yaitu pengguna BPMPKB, pengguna PIK remaja dan pengguna biasa. Sistem dibangun untuk memenuhi 8 kebutuhan fungsional aplikasi yang terdiri dari fungsional untuk pengguna biasa yang dapat melakukan pencarian PIK remaja berdasarkan kategori,nama dan wilayah dan dapat melakukan pencarian PIK remaja yang terdekat dari posisi pengguna serta dapat dapat melihat informasi PIK remaja seperti nomor SK, nama, alamat, pembina, jalur, dan kategori. Pengguna biasa juga dapat melihat rute menuju PIK remaja yang dipilih dari posisi user saat ini. Sebagai pengguna BPMPKB dapat mengelola data PIK remaja dan dapat mengunduh laporan dari setiap PIK remaja yang ada. Pengguna PIK remaja dapat mengunggah laporan serta dapat mengubah informasi PIK-nya Semua data dikelola dalam database yang dibangun dengan 9 tabel dengan 17 rancangan user interface aplikasi. Pengujian sistem telah dilakukan secara black-box testing oleh 5 orang pengguna menunjukkan aplikasi telah memenuhi semua kebutuhan fungsional aplikasi yang dirancang.

\section{REFERENSI}

[1] Amri, Muhammad Ulul. "Perbedaan Perilaku Seksual Remaja yang Mengikuti dan Tidak Mengikuti Pusat Informasi dan Konseling Remaja (PIK-R) pada Remaja SMU di Kabupaten Jember." (2013).

[2] Buzarudina, Frisa. "EFEKTIVITAS PENYULUHAN KESEHATAN REPRODUKSI REMAJA TERHADAP TINGKAT PENGETAHUAN SISWA SMAN 6 KECAMATAN PONTIANAK TIMUR TAHUN 2013." Jurnal Mahasiswa PSPD FK Universitas Tanjungpura 3, no. 1 (2013).

[3] Maolinda, Nisa. "Hubungan Pengetahuan dengan Sikap Siswa terhadap Pendidikan Kesehatan reproduksi Remaja di SMAN 1 Margahayu." Students e-Journal 1, no. 1 (2012): 28.

[4] Wulandari, Sri. "Hubungan Pengetahuan, Sikap Dan Perilaku Pencegahan Penyakit Menular Seksual (PMS) Dan HIV/AIDS Dengan Pemanfaatan Pusat Informasi Konseling Remaja (PIK-R) Pada Remaja SMKN Tandun Kabupaten Rokan Hulu." Jurnal Martenity and Neonatal 2, no. 1 (2015): 10-22.

[5] Fitri, Hayani. PERBEDAAN EFEKTIVITAS METODE PEMBELAJARAN AKTIF DAN CERAMAH TERHADAP TINGKAT PENGETAHUAN SEKSUALITAS REMAJA ANGGOTA PIK-R DI SMPN 13 PADANG TAHUN 2016. Diploma Thesis, Padang: Universitas Andalas, 2016.

[6] Adriansyah, Arya, Wahyudi Arifandi, and Narenda Wicaksono. "Keamanan Web Service." Teknik Informatika, Institut Teknologi Bandung, Bandung (2005).

[7] Primazni, Winadya. "SISTEM PELAPORAN DAN MONITORING KEGIATAN PUSAT INFORMASI DAN KONSELING REMAJA (PIK-R)(STUDI KASUS: DINAS BP2KB KOTA PARIAMAN)." PhD diss., Universitas Islam Negeri Sultan Syarif Kasim Riau, 2016.

[8] Hartadi, Yudhi, Haris Suryamen, and Fajril Akbar. "Perancangan Sistem Informasi Lokasi Lembaga Bimbingan Belajar di Kota Padang." Jurnal Teknologi dan Sistem Informasi 2, no. 1 (2016): 35-44.

[9] Suryamen, Haris, Ilham Aminuddin, and Fajril Akbar. "Pembangunan Sistem Informasi Geografis Lapangan Futsal Kota Padang Berbasis Web." Jurnal Teknologi dan Sistem Informasi 2, no. 1 (2016): 45-54.

[10] Junanda, Berry, Denny Kurniadi, and Yasdinul Huda. "PENCARIAN RUTE TERPENDEK MENGGUNAKAN ALGORITMA DIJKSTRA PADA SISTEM INFORMASI GEOGRAFIS PEMETAAN STASIUN PENGISIAN BAHAN BAKAR UMUM." Jurnal Vokasional Teknik Elektronika \& Informatika 4, no. 1 (2016).

[11] BKKBN. (2015). "Panduan pengelolaan Pusat Informasi \& Konseling Kesehatan Reproduksi Remaja”. Jakarta, BKKBN. 